Article

\title{
Understanding Farmers' Trait Preferences for Dual-Purpose Crops to Improve Mixed Crop-Livestock Systems in Zimbabwe
}

\author{
Mequanint B. Melesse ${ }^{1, *(\mathbb{D})}$, Amos Nyangira Tirra ${ }^{1}$, Chris O. Ojiewo $^{1} \mathbb{D}$ and Michael Hauser ${ }^{1,2}$ \\ 1 The International Crops Research Institute for the Semi-Arid Tropics (ICRISAT), \\ Nairobi P.O. Box 39063-00623, Kenya; amostirra@gmail.com (A.N.T.); C.Ojiewo@cgiar.org (C.O.O.); \\ M.Hauser@cgiar.org (M.H.) \\ 2 Department of Sustainable Agricultural Systems, University of Natural Resources and Life Sciences, \\ 1180 Vienna, Austria \\ * Correspondence: m.melesse@cgiar.org; Tel.: +254-715-093-444; Fax: +254-20-7224001
}

Citation: Melesse, M.B.; Tirra, A.N.; Ojiewo, C.O.; Hauser, M.

Understanding Farmers' Trait Preferences for Dual-Purpose Crops to Improve Mixed Crop-Livestock Systems in Zimbabwe. Sustainability 2021, 13, 5678. https://doi.org/ $10.3390 /$ su13105678

Academic Editor: Roberto Mancinelli

Received: 23 March 2021

Accepted: 12 May 2021

Published: 19 May 2021

Publisher's Note: MDPI stays neutral with regard to jurisdictional claims in published maps and institutional affiliations.

Copyright: (c) 2021 by the authors. Licensee MDPI, Basel, Switzerland. This article is an open access article distributed under the terms and conditions of the Creative Commons Attribution (CC BY) license (https:// creativecommons.org/licenses/by/ $4.0 /)$.

\begin{abstract}
Competition over land between food and fodder production, along with recurrent droughts and increasing population, has put mixed crop-livestock farming systems in the drylands of subSaharan Africa under pressure. Dual-purpose crops hold huge potential to ease this pressure and simultaneously improve food and fodder availability in these systems. We investigated farmers' preferences for dual-purpose maize, sorghum, and groundnut traits, and analyzed linkages of stated trait preferences with production of dual-purpose crops and adoption of improved varieties involving 645 households from two districts in Zimbabwe. The three target crops cover more than $75 \%$ of households' cropping lands. Highly preferred stated traits of dual-purpose crops include yield, disease resistance, and drought tolerance. Highly appreciated feed attributes encompass stover yield and digestibility. The adoption of improved varieties is high for maize but low for sorghum and groundnut. Trait preferences are correlated with the production of dual-purpose crops and the adoption of improved varieties of the crops. However, the strengths of these correlations differ for maize, sorghum, and groundnuts. We discuss these linkages and suggest why crop improvement programs should reconcile trade-offs between grain and feed attributes to support mixed croplivestock systems in Zimbabwe successfully.
\end{abstract}

Keywords: mixed farming system; maize; sorghum; groundnut; dual-purpose crops; trait preference; Zimbabwe

\section{Introduction}

Mixed crop-livestock farming systems dominate smallholder agriculture in many sub-Saharan African countries [1,2]. Crops provide food and income to households, while crop residues are an essential fodder source for livestock [3-5]. In return, livestock provides power and animal traction, livestock manure to increase soil fertility, and livestock improves the quality of human nutrition. In addition, livestock serves as a buffer against adverse climatic changes and other disasters. Finally, farmers use livestock sales to smooth consumption and invest in crop production [6-8]. Therefore, it is hard to imagine farming without the tight integration of crops and livestock in smallholder agriculture in sub-Sahara Africa.

Across Africa, smallholder agriculture is confronted with the degradation of natural resources, such as soils, land, water, and forests [9]. Relatedly, mixed crop-livestock farming systems are under increasing pressure as a result of intensified competition for land between crop and livestock production, along with recurrent droughts and an increasing human population $[10,11]$. For example, where land allocated by farmers to pasture has declined over time, feed production is at stake [12]. Because farmers in these systems live on meager resources and struggle with achieving household food security, much of the crop production is targeted for food, although crop residues are important livestock feed 
resources $[12,13]$. Therefore, feeding livestock adequately throughout the year remains a challenge for many smallholders in sub-Saharan Africa [14,15].

In response to livestock feeding challenges, farmers increasingly look for new options to improve their crop-livestock enterprises' productivity and efficiency [16]. One such option is dual-purpose crops that have a high potential to mitigate the land competition between food and feed through simultaneously enhancing grain yields and the availability and quality of livestock feed [15,17-19]. Compared with grain-only crops, dual-purpose crops help to improve the profitability, environmental sustainability, and resilience of the whole farm system substantially $[6,20]$. Dual-purpose crops can also offer great opportunity for intensifying farming systems.

As elsewhere in Africa, farmers in Zimbabwe rely heavily on mixed crop-livestock activities for their livelihood. Amongst the most important dual-purpose crops for farmers are maize (Zea mays), sorghum (Sorghum Bicolor L. Moench), and groundnut (Arachis hypogaea). These crops are the most important food crops for most of the country's predominantly rural population, while their residues are essential animal feed resources in the mixed crop-livestock systems [21]. In support of these farmers, most efforts by researchers for improving the quality of crop residues for feed have considerably focused on post-harvest interventions [18]. Traditionally, crop improvement programs of the national and international agricultural research community bred for higher grain yield and resistance to biotic and abiotic stress of varieties, ignoring biomass and other fodder attributes. However, recently, these crop improvement programs have shifted the focus to developing dual-purpose cultivars of maize, sorghum, and groundnuts [22,23].

Despite the recent reorientation of crop improvement programs, farmer adoption of improved dual-purpose crops is not a given. A farmer's decision to adopt a new variety is a complex process governed by social, economic, and technical factors [24,25]. Trait preferences of farmers further influence adoption, but these are not well documented for dual-purpose crops [11], and they are hardly available for Zimbabwe. Understanding farmers' perspectives and preferences for specific traits of dual-purpose crops is critical to inform breeding and the targeting and development of improved dual-purpose varieties by researchers.

In this study, we aim to contribute to the understanding of farmers' preferences for attributes of dual-purpose varieties of maize, sorghum, and groundnut and explore how these preferences are correlated with production of dual-purpose crops and adoption of improved varieties. We use choice models to evaluate how farmers' trait preferences and socioeconomic characteristic affect their production of dual-purpose crops and choice of crop varieties. The findings of this study will help to bring farmers' trait preferences and perspective into the discussion on the potential of dual-purpose crops in dryland systems.

\section{Dual-Purpose Crops in Zimbabwe}

In Zimbabwe, maize, sorghum, and groundnuts support the integration between crop and livestock enterprises in various forms, driving the development and research agenda. Shortage of feed, particularly during the dry season, has long been recognized as one of the major factors limiting livestock productivity in Zimbabwe $[10,26]$. This suggests a large role for dual-purpose crops to play in addressing this challenge in the country.

Previous studies have also documented that dual-purpose cultivars could mitigate feed shortages by increasing the available feed quantity and quality in the country [27]. The integration of crop and livestock enterprises is expected to enhance general technical efficiency and improve the input-to-output ratios of water, land, labor, and other inputs in the system [28]. Additionally, exploiting potential synergies between crop and livestock production can help farmers use the most of every resource in their mixed farming systems and avoid less optimal "early specialization" of the systems [28]. Similarly, dual-purpose crops could improve environmental outcomes and provide ways to mitigate risk and minimize adverse effects of long-term climate changes [8,20,29]. Dual-purpose crops can help smallholder farmers deal with trade-offs between competing uses of scarce land for 
food and feed production. This may also help reduce conflicts between crop and livestock farmers over land resources, especially trespass by nomadic communities.

In Zimbabwe, maize, sorghum, and groundnut are major crops in the mixed croplivestock systems. Figure 1 displays the land coverage and production trends for these crops over the last decade. Maize is an essential crop for food and feeds in Zimbabwean mixed crop-livestock systems [27]; it is the most widely grown cereal across the country in all agroecological zones. It accounts for about 80 to $90 \%$ of the total cereal area in Zimbabwe, with the annual area under the crop effectively exceeding one million hectares over the last ten years. Maize production is mostly rain-fed in Zimbabwe. As a result, maize production is hampered by frequent dry spells and erratic rainfall due to current climate change threats [30]. This is evident from Figure 1 as the land coverage and maize production has declined for the large part of the last decade.

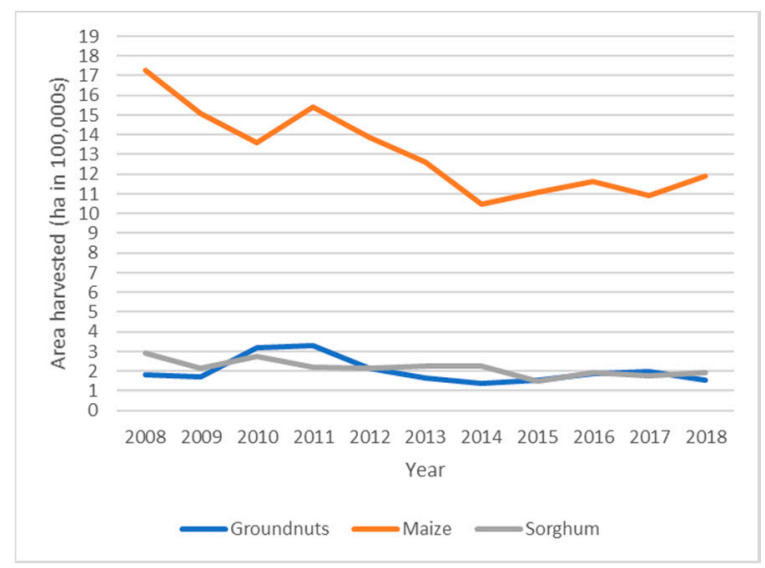

(a) Land coverage

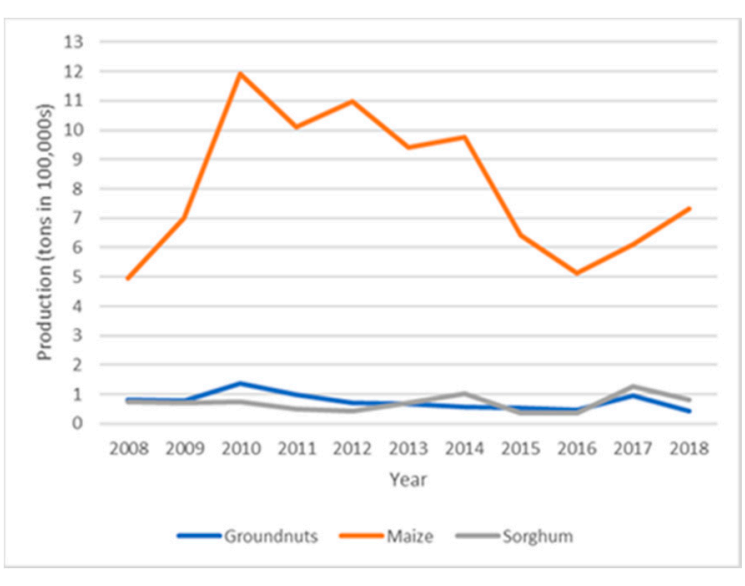

(b) Crop production

Figure 1. Land coverage (a) and production (b) trends for maize, sorghum, and groundnut in Zimbabwe. Source: FAOSTAT 2018.

Sorghum and groundnut are also relevant crops in terms of importance and area coverage in Zimbabwe. Sorghum is unique in its ability to grow under a wide array of harsh environmental conditions, making it a resilient crop widely used for food, feed, and beer brewing, especially in drylands where the adversities presented by climate change are substantial [31]. Residues of sorghum are an important source of dry season fodder for livestock [32]. Sorghum can be fed for livestock as wilted green chop, silage, and grain. It is primarily a feed energy source, with an estimated $65 \%$ total digestible nutrients. Similarly, groundnuts are an important source of Zimbabwe's food and income [9]. Groundnut haulms have a higher crude protein content compared to cereal residues and are a valuable source of supplementary feed during the dry season in mixed crop-livestock farming [33]. Groundnuts also contribute to soil fertility through biological nitrogen fixation.

Over the years, many improved maize, sorghum, and groundnut varieties have been developed and released in Zimbabwe. Under the Ministry of Agriculture, Mechanization and Irrigation Development, the Seed Services Institute has registered more than $100 \mathrm{im}-$ proved and hybrid varieties of maize, about 5 sorghum, and more than 15 groundnuts, developed for different purposes. Table 1 shows the most widely grown varieties of the three target crops and a summary of their main characteristics. Nationally, SC 513 is the most widely grown variety of maize. This is not surprising as it possesses the highly valued and preferred grain and field attributes by farmers. SC SILA and SC SMILE are the most preferred sorghum varieties in Zimbabwe, while Macia is an early-maturing variety with a terminal drought escape mechanism and wide agronomic adaptation. Nyanda and Ilanda are widely grown groundnut varieties. 
Table 1. Selected widely grown maize, sorghum and groundnut varieties and their associated characteristics in Zimbabwe.

\begin{tabular}{|c|c|c|c|c|}
\hline Variety & Local Name & $\begin{array}{l}\text { Release } \\
\text { Year }\end{array}$ & Main Preferred Trait(s) & Non-Preferred Trait(s) \\
\hline \multicolumn{5}{|c|}{ Maize } \\
\hline SC 513 & Mbizi & 1999 & Yield, earliness, drought tolerance & $\begin{array}{l}\text { Susceptible to ear rots, maize } \\
\text { streak virus }\end{array}$ \\
\hline SC 403 & Tsoko & 1998 & Earliness, drought tolerance & Susceptible to ear rots \\
\hline PAN 53 & PAN 53 & 2007 & $\begin{array}{l}\text { Appeal, nitrogen use efficiency, } \\
\text { drought tolerance }\end{array}$ & Susceptible to maize streak virus \\
\hline SC 727 & SC 727 & 2010 & $\begin{array}{l}\text { Yield, wide-area adaptability, } \\
\text { drought tolerance }\end{array}$ & Open tips, susceptible HT \\
\hline PHB 30G19 & PHB 30G19 & 2008 & $\begin{array}{c}\text { Drought tolerance, high bulk } \\
\text { density }\end{array}$ & Susceptible to maize streak virus \\
\hline SC 719 & SC 719 & 2004 & $\begin{array}{l}\text { Yield, wide-area adaptability, } \\
\text { biomass yield, drought tolerance }\end{array}$ & High ear placement \\
\hline \multicolumn{5}{|c|}{ Sorghum } \\
\hline SC SILA & SC SILA & 2004 & Yield, grain color & $\begin{array}{l}\text { Bird damage (highly preferred by } \\
\text { birds) }\end{array}$ \\
\hline SC Smile & SC Smile & 2011 & $\begin{array}{l}\text { Drought tolerance, earliness, plant } \\
\text { architecture }\end{array}$ & Susceptible to leaf blight \\
\hline Macia & Macia & 1998 & Yield, grain color, wide adaptation & $\begin{array}{l}\text { Bird damage (highly preferred by } \\
\text { birds) }\end{array}$ \\
\hline NS 5511 & NS 5511 & & Yield, market demand & Cost of seed is expensive \\
\hline \multicolumn{5}{|c|}{ Groundnut } \\
\hline $\begin{array}{l}\text { Natal } \\
\text { Common }\end{array}$ & Kasawaira & 1988 & Earliness and drought tolerance & $\begin{array}{l}\text { Susceptible to cercospora, web } \\
\text { blotch }\end{array}$ \\
\hline Nyanda & Nyanda & 2000 & Yield, drought tolerance & $\begin{array}{l}\text { Susceptible to ground rosette and } \\
\text { cercospora }\end{array}$ \\
\hline Jesa & Jesa & 1999 & Yield & Less preferred grain color \\
\hline Ilanda & Ilanda & 2006 & Grain color & $\begin{array}{l}\text { Susceptible to ground rosette and } \\
\text { cercospora }\end{array}$ \\
\hline Flamingo & Flamingo & 1982 & Yield, confectionery use & Susceptible to drought \\
\hline Makulu Red & Makulu Red & & Yield, confectionery use & Susceptible to drought \\
\hline
\end{tabular}

Source: Seed Services Institute, Ministry of Agriculture, Mechanization, and Irrigation Development.

Still, the potential of crop breeding to improve the quantity and quality of crop residuals is huge $[15,19]$, particularly in the Zimbabwean drylands where fodder is scarce. Assessments of the potential of dual-purpose cultivars for enhancing feed supply show that they can considerably increase feed quantity and quality to mitigate feed shortages [27]. Several studies show that grain yield, disease resistance, and drought tolerance or early maturity are the most important traits that farmers in Zimbabwe appreciate in their crops [30,34]. All these traits matter, especially given the potential that [35] estimated that a one-percentage unit increase in digestibility in sorghum and pearl millet stover would increase milk, meat, and draught power from 6 to 8\%. Unlocking such benefits in Zimbabwe would make important contributions to more sustainable livelihoods for farmers.

Given the potential benefits of dual-purpose crops, breeding and testing for dualpurpose cereals and legumes have attracted growing interest. Several ongoing dualpurpose crop improvement efforts seek to optimize both grain yield and feed quantity in many developing countries [15]. Nevertheless, for new varieties to succeed in Zimbabwe, crop breeders must account for end-user and market trait preferences in developing varieties. To this end, insights into farmers' demand for specific varietal attributes are useful for setting goals for crop improvement programs, optimizing limited resources in breeding programs, and motivating farmers to adopt improved varieties. 


\section{Methodology}

\subsection{Study Context, Sampling, and Data Collection}

Data were collected from the Gwanda and Mangwe districts of the Matabeleland South Province in Zimbabwe in 2019 (Figure 2). The districts were selected purposely to reflect the wide range of ecological conditions of mixed crop-livestock systems. They represent lowland semi-arid drylands of Zimbabwe, where fodder is relatively scarce with high potential for dual-purpose varieties. The districts are similar in terms of agricultural activities, agroecological development domains, market opportunities, and spatial population distribution.

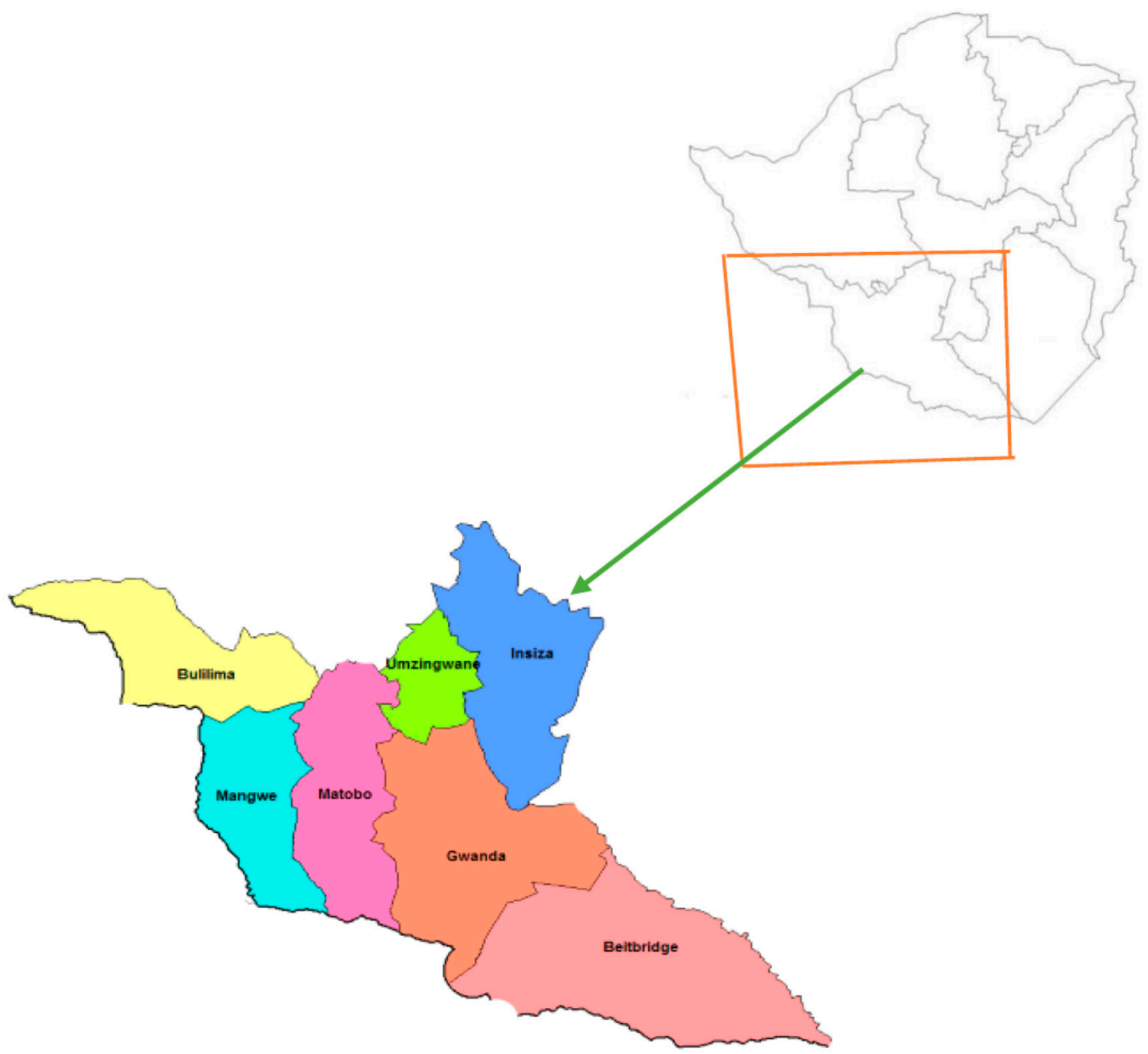

Figure 2. Map of Matabeleland South in Zimbabwe showing study districts.

Study households were selected from the two districts using a randomized three-stage sampling design. First, four wards (municipalities) from Gwanda district and six wards from Mangwe district were randomly chosen. Second, study villages were randomly selected. With most of the wards having six villages, three villages were randomly selected to represent study wards, resulting in 30 villages. Third, study households were sampled from sampling frames of selected villages using a sampling approach of the probability proportional to population distributions across the selected villages. Lists of households for sampling frames were accessed from village extension agents and local administrative offices, as appropriate. Following this procedure, 292 households in Gwanda and 353 households in Mangwe were surveyed, bringing the total number of surveyed households to 645 . 
A structured questionnaire was used to collect data from sampled households through face-to-face interviews. The survey covered several detailed modules at the individual, household, farm, and institutional levels. Individual characteristics include age, education, and gender of the household head, while household characteristics cover household size and assets. Farm characteristics include livestock and land use for different crops. Institutional factors encompass access to markets, extension, and credit. Particularly, detailed production information was collected on maize, sorghum, and groundnut.

We asked farmers whether they grow the target crops, over what area, and about their motivation to grow the crops. Farmers were also asked to evaluate the importance of traits of potential dual-purpose varieties of the crops on a simple four-point scale (not important, less important, important, or very important). As there are no studies available on feed traits of crops in the context of Zimbabwe, farmers were asked to rate the importance of grain and field attributes that include yield, resistance to disease, drought tolerance, and many feed quality and quantity attributes, such as biomass yield, stover yield, dry matter, digestibility, and lignin content. Key issues in using multiple items to measure farmers' preferences for dual-purpose crops are the validity and reliability of the different attributes. A principal component analysis was run to assess the degree of validity and reliability of the attributes.

\subsection{Statistical Analysis}

Detailed information on socioeconomic characteristics and farming systems of respondents were collected. Collected quantitative and qualitative data were coded, cleaned, and analyzed using the Stata software, version 16.1. Descriptive statistics were generated to summarize the social survey data and to describe respondents. Data on ratings of farmers' preferences for traits were categorical $(1=$ not important, $2=$ less important, $3=$ important, $4=$ very important). Assuming that differences between scale values are meaningful, ordinal categories can be viewed as interval numerical values [11,36]. Following this, we employed a comparison of means with pairwise t-tests to make statistical inferences about trait preference differences by gender and district.

We use binary probit and multinomial logit models to analyze how farmers' trait preferences and socioeconomic characteristics, respectively, affect their production of dualpurpose crops and choice of varieties of maize, sorghum, and groundnut. As production of dual-purpose crops is a binary choice outcome, the standard probit model is appropriate. Similarly, the multinomial logit model was used to test whether trait preferences and other factors affect farmers' choice of varieties, because of the categorical nature of the dependent variable, and the ease of estimation and interpretation of the coefficients [37]. Farmers grew different varieties, and, as a result, the dependent variable is the choice between three crop-variety categories: improved varieties; both improved and local varieties; local varieties. The local variety category was used as the reference category for the multinomial regressions. In both models, the independent variables included crop-specific attributes, and individual, household, and institutional variables.

\section{Results}

\subsection{Study Population and Farming Systems}

Table 2 summarizes the respondents' characteristics and presents information on simple mean difference tests for distributions of variables by study districts. About $60 \%$ of the respondents were males (Male), while the remaining $40 \%$ were female, suggesting a reasonably good gender balance in our sample. We report the main results disaggregated by gender throughout the article. The average respondent was about 57 years old (Age of household head) and had seven years of completed schooling (Education level), equivalent to an education level of primary school. This implies that extension and research service providers or "change agents" need to use vernacular language when communicating the nature and value of new agricultural technologies to these communities to promote adoption. The average household had about six family members (Household size) and 
operated on about 2.4 hectares of cultivable land (Land size) with a livestock herd of 11 tropical livestock units (TLU). Tropical livestock unit is a common unit to quantify various livestock species to a single figure to get the total amount of livestock owned by a household. We employed a tropical livestock unit applicable for SSA. The annual average per capita (farm and non-farm) income was Zimbabwean dollar (ZWD) 14,380 (Per capita income).

Table 2. Descriptive statistics of respondents.

\begin{tabular}{|c|c|c|c|}
\hline \multirow[b]{2}{*}{ Variable } & \multirow{2}{*}{$\begin{array}{c}\text { Pooled Data } \\
\text { Mean (std.dev) } \\
\quad(n=645)\end{array}$} & \multicolumn{2}{|c|}{ District } \\
\hline & & $\begin{array}{c}\text { Gwanda } \\
\text { Mean (std.dev) } \\
(n=292)\end{array}$ & $\begin{array}{c}\text { Mangwe } \\
\text { Mean (std.dev) } \\
(n=353)\end{array}$ \\
\hline \multirow{2}{*}{ Male $(1=$ gender of $\mathrm{HH}$ head is male; $0=$ otherwise $)$} & 0.60 & $0.64^{* *}$ & 0.57 \\
\hline & $(0.49)$ & $(0.48)$ & $(0.50)$ \\
\hline \multirow{2}{*}{ Age of household head (years) } & 57.47 & 55.77 & $58.87^{* * *}$ \\
\hline & (14.59) & $(14.57)$ & $(14.48)$ \\
\hline \multirow{2}{*}{ Household size (count) } & 5.74 & 5.77 & 5.71 \\
\hline & $(5.74)$ & $(2.88)$ & $(2.64)$ \\
\hline \multirow{2}{*}{ Education level (years of formal schooling) } & 7.43 & $8.36^{* * *}$ & 6.66 \\
\hline & $(7.43)$ & (3.39) & $(3.27)$ \\
\hline \multirow{2}{*}{ Land size (hectares) } & 2.35 & $2.56^{* * *}$ & 2.18 \\
\hline & $(1.57)$ & $(1.85)$ & $(1.28)$ \\
\hline \multirow{2}{*}{ Livestock owned (TLU) } & 11.10 & $13.98^{* * *}$ & 8.71 \\
\hline & $(13.82)$ & $(17.22)$ & $(9.58)$ \\
\hline \multirow{2}{*}{ Main occupation ( 1 = agriculture; 0 otherwise) } & 0.778 & 0.778 & 0.779 \\
\hline & $(0.415)$ & $(0.417)$ & $(0.415)$ \\
\hline \multirow{2}{*}{ Per capita income (ZWD) } & 14,380 & $16,811 *$ & 12,369 \\
\hline & $(32,043)$ & $(42,984)$ & $(18,497)$ \\
\hline Group membership $(1=$ member of a group; & 0.46 & $0.50 * *$ & 0.42 \\
\hline $0=$ otherwise) & $(0.50)$ & $(0.50)$ & $(0.49)$ \\
\hline \multirow{2}{*}{$\begin{array}{l}\text { Extension services }(1=\text { received extension services; } \\
\qquad 0=\text { otherwise })\end{array}$} & 0.76 & $0.84^{* * *}$ & 0.70 \\
\hline & $(0.43)$ & $(0.37)$ & $(0.46)$ \\
\hline \multirow{2}{*}{ Credit access $(1=$ access credit; $0=$ otherwise $)$} & 0.29 & 0.23 & $0.34^{* * *}$ \\
\hline & $(0.45)$ & $(0.42)$ & $(0.47)$ \\
\hline \multirow{2}{*}{ Distance to nearest village market (kilometers) } & 4.80 & 4.69 & 4.88 \\
\hline & $(6.91)$ & $(6.02)$ & $(7.57)$ \\
\hline
\end{tabular}

Source: Farmer survey. Standard deviation in parentheses; ${ }^{*} p<0.05 ;{ }^{* *} p<0.01 ;{ }^{* * *} p<0.001$.

As for institutional factors, a large proportion of the farming households $(76 \%)$ received extension services (Extension services), while only about $29 \%$ had credit access during the 12 months prior to the survey (Credit access). About $46 \%$ of farmers were members of a farmer group (Group membership). Farmers had relatively good access to village markets, with a $5 \mathrm{~km}$ average distance to the nearest village market (Distance to nearest village market). While farmers in Gwanda had better access to extension services and greater likelihood of participating in farmer groups, farmers in Mangwe had better credit access. Overall, the differences between male and female respondents were large in Gwanda; there, farmers owned more land and livestock and were younger and more educated than farmers in Mangwe District.

Farming systems in Gwanda and Mangwe are dominated by mixed crop-livestock systems. Table 3 summaries the crop varieties farmers grew during the survey. As expected, maize, sorghum, and groundnut are major crops in the study areas. Particularly, maize is grown by many farmers $(82 \%)$. Groundnut is the major legume crop in the study districts. Other common crops grown in the study areas include pearl millet, cowpeas, and Bambara 
nuts. Data from both districts showed that men and women participated equally in maize, sorghum, and groundnut farming activities.

Table 3. Crops grown and livestock owned in the study districts, percentage of farmers (\%).

\begin{tabular}{|c|c|c|c|c|c|}
\hline & \multirow{2}{*}{$\begin{array}{l}\text { Pooled Data } \\
\quad(n=645)\end{array}$} & \multicolumn{2}{|c|}{ Gender } & \multicolumn{2}{|c|}{ District } \\
\hline & & Male $(n=388)$ & Female $(n=257)$ & Gwanda $(n=292)$ & Mangwe $(n=353)$ \\
\hline \multicolumn{6}{|c|}{ Major crops } \\
\hline Maize & 82 & 84 & 79 & $90^{* * * *}$ & 76 \\
\hline Sorghum & 72 & 71 & 73 & 69 & 74 \\
\hline Groundnuts & 54 & 55 & 53 & $60^{* * *}$ & 50 \\
\hline Pearl millet & 43 & 43 & 44 & 14 & $67^{* * *}$ \\
\hline Cowpeas & 38 & 39 & 38 & $42 *$ & 35 \\
\hline Bambara nuts & 21 & 21 & 20 & 21 & 21 \\
\hline \multicolumn{6}{|c|}{ Livestock } \\
\hline Cattle & 63 & $67^{* * *}$ & 56 & 58 & $67^{* *}$ \\
\hline Goat & 93 & 94 & 91 & $99 * * *$ & 88 \\
\hline Sheep & 14 & 15 & 11 & 12 & 15 \\
\hline Horse/Donkey & 61 & $65^{* * *}$ & 54 & $74^{* * *}$ & 50 \\
\hline Chicken & 92 & 93 & 91 & $95^{* *}$ & 90 \\
\hline
\end{tabular}

Source: Farmer survey. ${ }^{*} p<0.05 ;{ }^{* *} p<0.01 ; * * *<0.001$.

Farmers in the study areas rear different types of livestock. Goat production is the most widely practiced livestock farming, a nearly universal practice in the Zimbabwe drylands. The level of external input and technology utilization in livestock production is generally low. About 85 and $92 \%$ of the respondents raised indigenous cattle and goat breeds, respectively. Farmers were also asked about the most important limiting constraints for cattle and goat production in the districts. Lack of fodder was the most limiting constraint for both cattle $(67 \%)$ and goat $(42 \%)$ production in the study areas. Other livestock production constraints mentioned by respondents included water scarcity and animal disease for cattle production (10\% and $9 \%$ of the respondents, respectively). Similarly, animal disease (26\%), theft $(13 \%)$, and water scarcity $(9 \%)$ were mentioned as the most important constraints for goat production.

Table 4 shows how integrated crop and livestock farming practices are in the study areas. Most surveyed farmers (88\%) used animal power to plow their land, with male farmers and respondents from Gwanda more likely to use animal traction. About $63 \%$ of the interviewed farmers applied manure to enhance soil fertility. Income from the sale of live animals and livestock products accounted for about $16 \%$ of the total household income. The contribution of livestock to household income was higher in Gwanda District. Similarly, the crop sector contributed to household food, income, and livestock feed. Eighty-two percent of farmers grazed and/or fed their livestock on crop residues.

We interviewed farmers about their livestock feeding practices and feeding composition. The primary livestock feed source is grazing rangelands, followed by crop residues (Table 4). Maize, sorghum, and groundnut residues are the most important crop residues in the two districts. About a quarter of the respondents purchased commercial concentrate for livestock feed. The study districts differed in livestock feeding on commercial concentrate; this being more intensive in Gwanda where nearly one third of farmers fed livestock on commercial concentrate. Dry fodder was a relevant livestock feed source for about $20 \%$ of the respondents. Generally, a small proportion of farmers fed their livestock on green fodder and home-made concentrate in the two districts. 
Table 4. Crop-livestock integration, and livestock feeding and marketing in the study districts.

\begin{tabular}{|c|c|c|c|c|c|}
\hline \multirow[b]{2}{*}{ Variable } & \multirow[b]{2}{*}{ Pooled Data $(n=645)$} & \multicolumn{2}{|c|}{ Gender } & \multicolumn{2}{|c|}{ District } \\
\hline & & $\begin{array}{c}\text { Male } \\
(n=388)\end{array}$ & $\begin{array}{c}\text { Female } \\
(n=257)\end{array}$ & $\begin{array}{l}\text { Gwanda } \\
(n=292)\end{array}$ & $\begin{array}{l}\text { Mangwe } \\
(n=353)\end{array}$ \\
\hline \multicolumn{6}{|c|}{ Panel A: Crop-livestock integration } \\
\hline Animal plow (\% of farmers) & 88 & $90 * *$ & 84 & $96^{* * *}$ & 81 \\
\hline Manure use (\% of farmers) & 63 & 65 & 60 & $66^{*}$ & 60 \\
\hline $\begin{array}{l}\text { Share of livestock income } \\
\text { from the total income }\end{array}$ & 16.32 & 16.98 & 15.30 & $23.86^{* * *}$ & 10.07 \\
\hline $\begin{array}{l}\text { Grazing and/or feeding crop } \\
\text { residue (\% of farmers) }\end{array}$ & 82 & $84^{* *}$ & 78 & 83 & 81 \\
\hline \multicolumn{6}{|c|}{ Panel B: Livestock feeding (\% of farmers) } \\
\hline Grazing rangelands & 91 & 92 & 89 & 88 & $93^{* *}$ \\
\hline Grazing crop residues & 57 & $60 *$ & 53 & 56 & 58 \\
\hline Feeding crop residues & 57 & $60 *$ & 52 & $63^{* * *}$ & 52 \\
\hline Feeding dry fodder & 20 & 21 & 17 & $23^{* *}$ & 16 \\
\hline Feeding green fodder & 7 & $9 * *$ & 5 & $11^{* * *}$ & 4 \\
\hline Commercial concentrate & 24 & $26^{*}$ & 20 & $30^{* * *}$ & 18 \\
\hline Home-made concentrate & 8 & 8 & 8 & 8 & 8 \\
\hline Mucuna and/or sunhemp & 5 & 5 & 4 & $8^{* * *}$ & 2 \\
\hline \multicolumn{6}{|c|}{ Panel C: Livestock marketing (\% of farmers who sell) } \\
\hline Cattle & 19 & 21 & 16 & $23^{* *}$ & 16 \\
\hline Goats & 34 & $38^{* * *}$ & 28 & $58^{* * *}$ & 15 \\
\hline Milk & 1.00 & 1.00 & 0.00 & 1.00 & 0.00 \\
\hline Processed feed & 1.00 & $1.00 *$ & 0.00 & 1.00 & 1.00 \\
\hline
\end{tabular}

Source: Farmer survey. ${ }^{*} p<0.05 ;{ }^{* *} p<0.01 ;{ }^{* * *} p<0.001$.

Finally, interviewed farmers participated in livestock marketing. The proportion of farmers who sold livestock was higher in Gwanda than in Mangwe (Table 4). Sales of goats were more frequent than that of cattle. More farmers sold goats in Gwanda (58\%) than in Mangwe (15\%). Generally, milk and processed feed sales are not good sources of income in the study areas. Farmers were asked about the constraints they faced in livestock marketing. Low and fluctuating market price and exploitation by middlemen were the most limiting constraints, followed by market information-related challenges (e.g., difficulty in reaching potential buyers and lack of grade and price information) and poor market access.

\subsection{Importance of Maize, Sorghum, and Groundnut in Mixed Farming Systems}

The three crops, particularly maize, are grown by a large portion of smallholder farmers in the study districts (Table 5). These crops are frequently grown in every main season by a great majority of farmers. Almost all growers of the crops reported growing them every year. Another important indicator of the importance of the crops in farmers livelihood is the proportion of land allocated to the crops. The intensity of land was measured as the percentage of total cropped land allocated towards the specific crop during the season. Altogether, maize, sorghum, and groundnut accounted, on average, for $75 \%$ of a households' land. Particularly, the proportion of land area allocated to maize and sorghum cultivation was highest, accounting for about $60 \%$ of the household land. Generally, there were no gender and district differences in the proportion of household land allocated to the crops. However, the area under all crops was higher in Gwanda than in Mangwe. 
Table 5. Importance of maize, sorghum, and groundnut by gender and district among growing farmers.

\begin{tabular}{|c|c|c|c|c|c|}
\hline \multirow{2}{*}{ Variable } & \multirow{2}{*}{ Pooled Data } & \multicolumn{2}{|c|}{ Gender } & \multicolumn{2}{|c|}{ District } \\
\hline & & Male & Female & Gwanda & Mangwe \\
\hline Maize & $n=531$ & $n=327$ & $n=204$ & $n=264$ & $n=267$ \\
\hline Growing the crop every year (\%) & 97.36 & $98.47^{* *}$ & 95.59 & 95.83 & $98.88^{* *}$ \\
\hline Area of land allocated (ha) & 0.71 & 0.73 & 0.68 & $0.82^{* * *}$ & 0.61 \\
\hline $\begin{array}{c}\text { Proportion of household land } \\
\text { allocated }(\%)\end{array}$ & 29 & 29 & 29 & 31 & 27 \\
\hline \multicolumn{6}{|l|}{$\begin{array}{l}\text { Main purpose of grain (\% of total } \\
\text { production) }\end{array}$} \\
\hline Household consumption (\%) & 67 & $81^{* * *}$ & 45 & $77^{* * *}$ & 60 \\
\hline Animal feed $(\%)$ & 4 & 0 & $11^{* * *}$ & 0 & $8^{* * *}$ \\
\hline Saved for seed (\%) & 2 & 3 & 1 & $3^{*}$ & 1 \\
\hline Sale $(\%)$ & 24 & 14 & $40 * * *$ & 16 & $30^{* * *}$ \\
\hline Gifts, barter, and other (\%) & 2 & 2 & 2 & $3^{*}$ & 1 \\
\hline Sorghum & $n=463$ & $n=275$ & $n=188$ & $n=201$ & $n=262$ \\
\hline Growing the crop every year $(\%)$ & 98.70 & $99.64^{* *}$ & 97.34 & 98.01 & 99.24 \\
\hline Area of land allocated (ha) & 0.80 & 0.81 & 0.79 & $0.95^{* * *}$ & 0.69 \\
\hline $\begin{array}{c}\text { Proportion of household land } \\
\text { allocated }(\%)\end{array}$ & 32 & 31 & 33 & 35 & 30 \\
\hline \multicolumn{6}{|l|}{$\begin{array}{l}\text { Main purpose of grain (\% of total } \\
\text { production) }\end{array}$} \\
\hline Household consumption (\%) & 87 & 86 & 89 & 86 & 88 \\
\hline Animal feed $(\%)$ & 1 & 1 & 1 & 1 & 1 \\
\hline Saved for seed (\%) & 7 & 7 & 6 & 6 & 8 \\
\hline Sale $(\%)$ & 1 & 1 & 0 & 1 & 0 \\
\hline Gifts, barter, and other (\%) & 0 & 0 & 0 & 0 & 0 \\
\hline Groundnut & $n=350$ & $n=215$ & $n=135$ & $n=175$ & $n=175$ \\
\hline Growing the crop every year (\%) & 96.57 & 95.81 & 97.78 & 94.86 & $98.29 *$ \\
\hline Area of land allocated (ha) & 0.36 & $0.40 * *$ & 0.36 & $0.42 * *$ & 0.30 \\
\hline $\begin{array}{c}\text { Proportion of household land } \\
\text { allocated (\%) }\end{array}$ & 14 & 16 & 12 & 15 & 13 \\
\hline \multicolumn{6}{|l|}{$\begin{array}{l}\text { Main purpose of grain (\% of total } \\
\text { production) }\end{array}$} \\
\hline Household consumption (\%) & 65 & 65 & 69 & 67 & 62 \\
\hline Animal feed $(\%)$ & 0 & 0 & 0 & 0 & 0 \\
\hline Saved for seed (\%) & 10 & 9 & $17^{* *}$ & 10 & 9 \\
\hline Sale $(\%)$ & 18 & 19 & 13 & 14 & $29^{* * *}$ \\
\hline Gifts, barter, and other (\%) & 7 & $8^{*}$ & 3 & $9^{* * *}$ & 0 \\
\hline
\end{tabular}

Source: Farmer survey. ${ }^{*} p<0.05 ;{ }^{* *} p<0.01 ;{ }^{* * *} p<0.001$.

The purposes of the grains of the crops were also assessed in the survey. The primary motivation of farmers for growing these crops was grain. The grains of all crops were used primarily for household consumption. Specifically, sorghum grains were used almost entirely for home consumption and seed. Grain sales were ranked as the second most important use for maize $(24 \%)$ and groundnuts $(18 \%)$. Overall, grains were rarely used for animal feed, though most farmers reported using crop residues for animal feed (Table 5). While more male respondents reported using maize grains for consumption, female respondents were more likely to sell and use maize grains for animal feed. Other major motivations for growing the crops were fodder, crop rotation, and soil and climate suitability. 


\subsection{Farmers' Preferences for Dual-Purpose Crop Traits}

We assessed the validity and reliability of the attributes using a principal component analysis. The results of the principal component analysis are shown in Table 6. Grain and field attributes and feed attributes measure distinct preferences for dual-purpose varieties. Consistently, grain and field attributes and feed attributes load onto different components. Furthermore, all attributes of a specific group load onto the same componentfeed attributes on component 1 and grain and field attributes on component 2 -for all crops. This supports the validity that all the attributes of a specific group reflect the same underlying construct, which maximizes the internal reliability and facilitates the interpretation of the scores of the attributes. The weights of individual attributes on the respective components are also reasonably high. Overall, the average of attribute weights on a given component is about 0.8 , supporting the internal consistency of that specific group's attributes.

Table 6. Principal component analysis results.

\begin{tabular}{ccccccc}
\hline \multirow{2}{*}{ Attributes } & \multicolumn{2}{c}{ Maize } & \multicolumn{2}{c}{ Sorghum } & \multicolumn{2}{c}{ Groundnuts } \\
\cline { 2 - 7 } & Comp. 1 & Comp. 2 & Comp. 1 & Comp. 2 & Comp. 1 & Comp. 2 \\
\hline Grain yield & 0.090 & $\mathbf{0 . 8 6 7}$ & 0.117 & $\mathbf{0 . 8 1 0}$ & 0.103 & $\mathbf{0 . 8 1 7}$ \\
\hline $\begin{array}{c}\text { Disease } \\
\text { resistance }\end{array}$ & 0.401 & $\mathbf{0 . 4 9 2}$ & 0.401 & $\mathbf{0 . 5 2 2}$ & 0.248 & $\mathbf{0 . 7 3 0}$ \\
\hline $\begin{array}{c}\text { Drought } \\
\text { tolerance }\end{array}$ & 0.066 & $\mathbf{0 . 8 5 4}$ & 0.076 & $\mathbf{0 . 8 1 7}$ & 0.196 & $\mathbf{0 . 7 5 4}$ \\
\hline Stover yield & $\mathbf{0 . 8 3 6}$ & 0.099 & $\mathbf{0 . 8 3 5}$ & 0.154 & $\mathbf{0 . 8 3 7}$ & 0.199 \\
\hline Dry matter & $\mathbf{0 . 7 9 2}$ & 0.089 & $\mathbf{0 . 8 1 7}$ & 0.170 & $\mathbf{0 . 8 2 6}$ & 0.139 \\
\hline Stay green & $\mathbf{0 . 8 0 2}$ & 0.055 & $\mathbf{0 . 8 1 7}$ & 0.111 & $\mathbf{0 . 7 5 5}$ & 0.243 \\
\hline Low lignin & $\mathbf{0 . 8 2 5}$ & 0.136 & $\mathbf{0 . 8 0 4}$ & 0.238 & $\mathbf{0 . 8 2 2}$ & 0.218 \\
\hline Digestibility & $\mathbf{0 . 7 7 8}$ & 0.214 & $\mathbf{0 . 7 3 4}$ & 0.362 & $\mathbf{0 . 7 7 9}$ & 0.304 \\
\hline Biomass yield & $\mathbf{0 . 6 7 1}$ & 0.031 & $\mathbf{0 . 7 3 1}$ & 0.053 & $\mathbf{0 . 6 9 8}$ & 0.079 \\
\hline
\end{tabular}

Source: Author's analysis based on farmer survey data. Bolded coefficients indicate preferred factor loadings.

Farmers were asked to rate the importance of the different traits when selecting the three crops for growing for dual-purpose (Table 7). Farmers considered a wide range of attributes when selecting a variety for dual-purpose. In the field and grain attributes, yield is the most important trait for all three crops, with a score of 3.78 for sorghum, 3.82 for groundnut, and 3.91 for maize out of 4 . For maize and sorghum, male respondents and respondents from Mangwe tended to emphasize yield more importance than female respondents and respondents from Gwanda. Similarly, drought tolerance and resistance to disease were highly valued attributes for farmers, both of which generally received scores above 3.5 out of 4 across both genders and districts. Male respondents valued drought tolerance and resistance to disease more than female respondents for maize. Overall, there are no noticeable differences between grain and field traits of groundnut by gender and district. 
Table 7. Importance of traits of maize, sorghum, and groundnut for dual-purpose by gender and district (average farmer responses on a scale of $1=$ not important, $2=$ less important, $3=$ important, $4=$ most important).

\begin{tabular}{|c|c|c|c|c|c|}
\hline \multirow[b]{2}{*}{ Traits } & \multirow{2}{*}{$\begin{array}{l}\text { Pooled Data } \\
\quad(n=645)\end{array}$} & \multicolumn{2}{|c|}{ Gender } & \multicolumn{2}{|c|}{ District } \\
\hline & & $\begin{array}{c}\text { Male } \\
(n=388)\end{array}$ & $\begin{array}{c}\text { Female } \\
(n=257)\end{array}$ & $\begin{array}{l}\text { Gwanda } \\
(n=292)\end{array}$ & $\begin{array}{l}\text { Mangwe } \\
(n=353)\end{array}$ \\
\hline \multicolumn{6}{|c|}{ Maize } \\
\hline \multicolumn{6}{|c|}{ Grain and field attributes } \\
\hline Grain yield & 3.91 & $3.93 * *$ & 3.88 & 3.88 & $3.94 * *$ \\
\hline Drought tolerance & 3.76 & $3.80^{* * *}$ & 3.70 & 3.73 & 3.78 \\
\hline Disease resistance & 3.67 & $3.71 *$ & 3.62 & 3.67 & 3.68 \\
\hline \multicolumn{6}{|l|}{ Feed attributes } \\
\hline Biomass yield & 2.98 & 2.99 & 2.95 & 2.87 & $3.07^{* * *}$ \\
\hline Digestibility & 3.02 & 3.05 & 2.97 & 2.86 & $3.15^{* * *}$ \\
\hline Low lignin & 2.92 & $2.99 * *$ & 2.82 & 2.80 & $3.02^{* * *}$ \\
\hline Stay green & 2.90 & $2.95 *$ & 2.82 & 2.84 & 2.94 \\
\hline Stover yield & 3.16 & 3.19 & 3.11 & 3.12 & 3.19 \\
\hline Dry matter & 2.97 & 2.98 & 2.96 & 2.75 & $3.16^{* * *}$ \\
\hline \multicolumn{6}{|c|}{ Sorghum } \\
\hline \multicolumn{6}{|c|}{ Grain and field attributes } \\
\hline Grain yield & 3.78 & $3.79 * * *$ & 3.77 & 3.72 & $3.84^{* * *}$ \\
\hline Drought tolerance & 3.70 & 3.67 & 3.74 & 3.67 & 3.71 \\
\hline \multirow{2}{*}{\multicolumn{6}{|c|}{ Feed attributes }} \\
\hline & & & & & \\
\hline Biomass yield & 2.93 & 2.96 & 2.89 & 2.80 & $3.05^{* * *}$ \\
\hline Digestibility & 3.02 & $3.08 * *$ & 2.94 & 2.85 & $3.16^{* * *}$ \\
\hline Low lignin & 2.89 & 2.93 & 2.82 & 2.77 & $2.99^{* * *}$ \\
\hline Stay green & 2.84 & 2.88 & 2.79 & 2.79 & 2.89 \\
\hline Stover yield & 3.16 & 3.19 & 3.11 & 3.10 & 3.20 \\
\hline \multirow[t]{2}{*}{ Dry matter } & 2.97 & 2.99 & 2.93 & 2.73 & $3.16^{* * *}$ \\
\hline & \multicolumn{5}{|c|}{ Groundnut } \\
\hline \multicolumn{6}{|c|}{ Grain and field attributes } \\
\hline Grain yield & 3.80 & 3.82 & 3.77 & 3.79 & 3.81 \\
\hline Drought tolerance & 3.70 & 3.69 & 3.72 & 3.67 & 3.73 \\
\hline Disease resistance & 3.62 & 3.60 & 3.64 & 3.58 & 3.65 \\
\hline \multicolumn{4}{|l|}{ Feed attributes } & & $3.15^{* * *}$ \\
\hline Digestibility & 3.59 & $3.68^{* *}$ & 3.44 & 3.46 & $3.69^{* *}$ \\
\hline Low lignin & 2.98 & 2.99 & 2.96 & 2.85 & $3.09^{* * *}$ \\
\hline Stay green & 2.93 & 2.95 & 2.90 & 2.90 & 2.95 \\
\hline Stover yield & 3.08 & 3.07 & 3.08 & 3.02 & 3.12 \\
\hline Dry matter & 2.97 & 2.96 & 2.98 & 2.76 & $3.14^{* * *}$ \\
\hline
\end{tabular}

Source: Farmer survey. ${ }^{*} p<0.05 ;{ }^{* *} p<0.01 ;{ }^{* * *} p<0.001$.

Similarly, farmers showed high interest in many feed attributes. Stover yield and digestibility are the first group of most important attributes, with scores from 3.02 to 3.59. The next most important group of feeding attributes consists of biomass yield, low lignin, stay green, and dry matter, all of which received scores of 2.9 to 3.0 across all crops. For feed attributes, there were only slight differences by gender of respondents. Male respondents placed higher importance on stay green and low lignin attributes of maize and digestibility of stover for sorghum and groundnut than did female respondents. However, there were major differences in the importance of many feed attributes by district. Overall, respondents in Mangwe placed higher importance on many feed attributes across the three crops. 


\subsection{Trait Preferences and Adoption of Dual-Purpose Crops and Varieties}

Table 8 reports adoption levels of improved varieties of target crops by smallholder farmers. Improved maize varieties are by far most widely adopted ( $87 \%)$. The adoption rates of maize varieties are compatible with many improved varieties of the crop. Amongst many African developing countries, Zimbabwe has one of the highest adoption rates of hybrid maize varieties. Previous studies have revealed that adoption rates of improved maize varieties in Zimbabwe are generally above $80 \%$ [30]. At the same time, a great majority of farmers are growing local varieties of sorghum (67\%) and groundnut (73\%). Furthermore, $82 \%$ of the farmers reported growing cereals and legumes (not limited to maize, sorghum, and groundnut) for dual-purpose, although this was mostly considering the crop residual or stover yield potential of crops.

Table 8. Adoption levels of improved varieties among growers of target crops (percentage of growing respondents) in Gwanda and Mangwe districts.

\begin{tabular}{|c|c|c|c|c|c|}
\hline \multirow{2}{*}{ Varieties } & \multirow{2}{*}{ Pooled Data } & \multicolumn{2}{|c|}{ Gender } & \multicolumn{2}{|c|}{ District } \\
\hline & & Male & Female & Gwanda & Mangwe \\
\hline Maize & $n=531$ & $n=327$ & $n=204$ & $n=264$ & $n=267$ \\
\hline Local & 11.68 & 12.84 & 9.80 & $15.15^{* *}$ & 8.24 \\
\hline Improved & 86.82 & 85.32 & 89.22 & 83.33 & $90.26 * *$ \\
\hline Both & 1.51 & 1.83 & 0.98 & 1.52 & 1.50 \\
\hline Sorghum & $n=463$ & $n=275$ & $n=188$ & $n=201$ & $n=262$ \\
\hline Local & 67.39 & 65.82 & 69.68 & 67.16 & 67.56 \\
\hline Improved & 31.53 & 33.82 & 28.19 & 31.84 & 31.30 \\
\hline Both & 1.08 & 0.36 & $2.13 *$ & 1.00 & 1.15 \\
\hline Groundnut & $n=350$ & $n=215$ & $n=135$ & $n=175$ & $n=175$ \\
\hline Local & 72.57 & 73.95 & 70.37 & 68.57 & $76.57 *$ \\
\hline Improved & 27.14 & 25.58 & 29.63 & 30.86 & 23.43 \\
\hline Both & 0.29 & 0.47 & 0.00 & 0.57 & 0.00 \\
\hline
\end{tabular}

Source: Farmer survey. ${ }^{*} p<0.05 ;{ }^{* *} p<0.01$.

We used choice models to explore how farmers' preferences for specific traits are associated with production of dual-purpose crops and adopting improved varieties of maize, sorghum, and groundnut. Table 9 reports results estimated using a probit model to analyze determinants of the likelihood of producing dual-purpose crops. The results indicate that different farmers' preferences for traits across the three crops are positively and significantly associated with a household's likelihood of producing crops for dualpurpose. Specifically, farmers who valued feed attributes of stover yield, biomass, and stay green traits important in their choice of varieties were more likely to grow dualpurpose crops. Maize and groundnut farmers who reported drought tolerance an important attribute were also more likely to grow dual-purpose crops. However, grain yield is significantly and negatively correlated with the likelihood of producing dual-purpose crops by maize farmers, perhaps suggesting the possibility of trade-offs between grain and feed attributes in dual-purpose varieties. Table 9 also shows that socioeconomic characteristics of farmers affect their likelihood of producing dual-purpose crops. As expected, farmers who owned more livestock and who fed their livestock on residue were more likely to grow dual-purpose varieties. The likelihood of producing dual-purpose crops increases with household size, fertilizer application, and credit access, but decreases with distance to market and off-farm income opportunities. 
Table 9. Factors affecting farmers' production of dual-purpose crops (local, improved) in Zimbabwe (probit model).

\begin{tabular}{|c|c|c|c|}
\hline & Maize & Sorghum & Groundnut \\
\hline \multirow{2}{*}{ Male household head } & 0.153 & 0.159 & 0.205 \\
\hline & $(0.140)$ & $(0.143)$ & $(0.141)$ \\
\hline \multirow{2}{*}{ Age } & 0.002 & -0.001 & 0.001 \\
\hline & $(0.005)$ & $(0.005)$ & $(0.005)$ \\
\hline \multirow{2}{*}{ Years of education } & 0.028 & 0.021 & 0.026 \\
\hline & $(0.021)$ & $(0.022)$ & $(0.022)$ \\
\hline \multirow{2}{*}{ Household size } & $0.052 * *$ & $0.049 *$ & $0.047^{*}$ \\
\hline & $(0.026)$ & $(0.026)$ & $(0.026)$ \\
\hline \multirow{2}{*}{ Farming main occupation } & 0.014 & 0.039 & 0.052 \\
\hline & $(0.169)$ & $(0.170)$ & $(0.169)$ \\
\hline \multirow{2}{*}{ TLU } & 0.012 * & $0.015^{* *}$ & 0.012 * \\
\hline & $(0.007)$ & $(0.007)$ & $(0.007)$ \\
\hline \multirow{2}{*}{ Group membership } & 0.065 & 0.079 & 0.074 \\
\hline & $(0.141)$ & $(0.143)$ & $(0.141)$ \\
\hline \multirow{2}{*}{ Extension services } & 0.217 & 0.153 & 0.179 \\
\hline & $(0.158)$ & $(0.156)$ & $(0.155)$ \\
\hline \multirow{2}{*}{ Credit access } & 0.268 * & $0.261^{*}$ & $0.231^{*}$ \\
\hline & $(0.152)$ & $(0.154)$ & $(0.155)$ \\
\hline \multirow{2}{*}{ Distance to market } & $-0.003^{*}$ & $-0.003^{*}$ & $-0.003^{*}$ \\
\hline & $(0.002)$ & $(0.002)$ & $(0.002)$ \\
\hline \multirow{2}{*}{ Fertilizer application } & $0.991^{* * *}$ & $0.893^{* *}$ & $1.005^{* * *}$ \\
\hline & $(0.360)$ & $(0.367)$ & $(0.367)$ \\
\hline \multirow{2}{*}{ Residue use } & $0.522^{* * *}$ & $0.481^{* * *}$ & $0.576^{* * *}$ \\
\hline & $(0.162)$ & $(0.163)$ & $(0.166)$ \\
\hline \multirow{2}{*}{ Off-farm income } & $-0.357^{* *}$ & $-0.305^{*}$ & $-0.318^{* *}$ \\
\hline & $(0.161)$ & $(0.163)$ & $(0.157)$ \\
\hline \multirow{2}{*}{ Grain yield } & $-0.546^{* *}$ & -0.090 & 0.082 \\
\hline & $(0.256)$ & $(0.169)$ & $(0.152)$ \\
\hline \multirow{2}{*}{ Drought tolerance } & $0.365^{* *}$ & 0.054 & $0.227^{*}$ \\
\hline & $(0.162)$ & $(0.150)$ & $(0.136)$ \\
\hline \multirow{2}{*}{ Disease resistance } & -0.173 & $0.355^{* * *}$ & -0.093 \\
\hline & $(0.124)$ & $(0.108)$ & $(0.120)$ \\
\hline \multirow{2}{*}{ Stover yield } & $0.272 * *$ & $0.343^{* *}$ & $0.145^{* *}$ \\
\hline & $(0.129)$ & $(0.136)$ & $(0.137)$ \\
\hline \multirow{2}{*}{ Digestibility } & 0.117 & -0.126 & 0.053 \\
\hline & $(0.111)$ & $(0.111)$ & $(0.123)$ \\
\hline \multirow{2}{*}{ Biomass } & $0.012 *$ & $0.144^{* *}$ & $0.023^{* *}$ \\
\hline & $(0.091)$ & $(0.091)$ & $(0.092)$ \\
\hline \multirow{2}{*}{ Low lignin } & 0.071 & -0.008 & -0.121 \\
\hline & $(0.105)$ & $(0.107)$ & $(0.082)$ \\
\hline \multirow{2}{*}{ Stay green } & 0.164 * & $0.144^{* *}$ & $0.317^{* * *}$ \\
\hline & $(0.096)$ & $(0.100)$ & $(0.099)$ \\
\hline \multirow{2}{*}{ Dry matter } & -0.029 & -0.072 & 0.171 \\
\hline & $(0.114)$ & $(0.130)$ & $(0.119)$ \\
\hline Constant & -0.479 & $-2.314^{* * *}$ & $-2.403^{* * *}$ \\
\hline Constant & $(0.919)$ & $(0.761)$ & $(0.681)$ \\
\hline Observations & 645 & 645 & 645 \\
\hline Prob > chi2 & 0.000 & 0.000 & 0.000 \\
\hline Pseudo $\mathrm{R}^{2}$ & 0.176 & 0.202 & 0.186 \\
\hline
\end{tabular}


Similarly, a multinomial logit model was estimated to identify factors influencing adoption of improved varieties of maize, sorghum, and groundnut among farming households. Crop farmers were faced with three discrete choices of growing only improved varieties, growing both improved and local varieties, or growing only local varieties, the base category in the regression (Table 10). The results reveal that farmers' preferences for certain traits are significantly associated with adopting improved varieties of maize, sorghum, and groundnut. Specifically, grain yield and drought tolerance are important grain and field traits that are positively and significantly associated with the probability of adopting improved varieties of the crops. The results also indicate that improved varieties that score well on such feed characteristics as biomass and stover yield could have a higher probability of being adopted. However, sorghum farmers who valued low lignin important in their variety choices were less likely to adopt improved varieties of the crop. Table 10 also shows that certain socioeconomic characteristics of farmers are important determinants of adoption of improved varieties of the crops. A farmer's likelihood of growing improved varieties increases with extension services and fertilizer application, probably indicating the importance of rural services and complementarity of other technologies to improve farmers' adoption of improved varieties. The probability of growing improved maize varieties increases with age, credit access, and education levels. The likelihood of adopting maize and improved sorghum varieties also increases with household size. However, households who were headed by a male and whose main occupation was farming were less likely to adopt improved varieties.

Table 10. Factors driving the choice of crop varieties in Zimbabwe (multinomial logit model).

\begin{tabular}{|c|c|c|c|c|c|c|}
\hline & \multicolumn{2}{|c|}{ Maize Varieties } & \multicolumn{2}{|c|}{ Sorghum Varieties } & \multicolumn{2}{|c|}{ Groundnut Varieties } \\
\hline & Improved & $\begin{array}{l}\text { Improved } \\
\text { and Local }\end{array}$ & Improved & $\begin{array}{l}\text { Improved } \\
\text { and Local }\end{array}$ & Improved & $\begin{array}{l}\text { Improved } \\
\text { and Local }\end{array}$ \\
\hline \multirow{2}{*}{$\begin{array}{l}\text { Male household } \\
\text { head }\end{array}$} & $-0.553 *$ & 1.746 & $-0.090 *$ & -369.296 & $-0.505 *$ & 5.078 \\
\hline & $(0.332)$ & $(1.493)$ & $(0.242)$ & $(524.848)$ & $(0.290)$ & (5111.184) \\
\hline \multirow{2}{*}{ Age } & 0.019 * & -0.017 & -0.004 & -18.056 & -0.012 & -0.143 \\
\hline & $(0.011)$ & $(0.038)$ & $(0.009)$ & $(24.840)$ & $(0.010)$ & $(232.394)$ \\
\hline \multirow{2}{*}{ Years of education } & $0.102^{* *}$ & -0.306 & 0.038 & -27.682 & 0.021 & 0.846 \\
\hline & $(0.048)$ & $(0.231)$ & $(0.038)$ & $(37.897)$ & $(0.045)$ & (1113.148) \\
\hline \multirow{2}{*}{ Household size } & $0.062 *$ & 0.026 & $0.077^{* *}$ & -57.351 & 0.035 & 1.131 \\
\hline & $(0.057)$ & $(0.304)$ & $(0.039)$ & $(77.160)$ & $(0.047)$ & $(637.152)$ \\
\hline \multirow{2}{*}{$\begin{array}{l}\text { Farming main } \\
\text { occupation }\end{array}$} & $-1.405^{* * *}$ & $-2.536 *$ & -0.101 & 560.636 & $-0.529 *$ & -3.997 \\
\hline & $(0.513)$ & $(1.510)$ & $(0.293)$ & $(799.885)$ & $(0.346)$ & $(5651.091)$ \\
\hline \multirow{2}{*}{ TLU } & -0.002 & -0.015 & -0.011 & 13.847 & 0.010 & -0.232 \\
\hline & $(0.010)$ & $(0.037)$ & $(0.011)$ & $(18.992)$ & $(0.012)$ & $(304.743)$ \\
\hline Group & 0.071 & 0.199 & 0.321 & -172.286 & 0.341 & -7.262 \\
\hline membership & $(0.307)$ & $(1.118)$ & $(0.232)$ & $(242.571)$ & $(0.280)$ & $(6171.405)$ \\
\hline \multirow{2}{*}{ Extension services } & $0.095^{* *}$ & -0.511 & $1.295^{* * *}$ & -252.194 & $0.573^{* *}$ & 6.896 \\
\hline & $(0.380)$ & $(1.256)$ & $(0.347)$ & $(354.133)$ & $(0.371)$ & $(5677.220)$ \\
\hline \multirow{2}{*}{ Credit access } & $0.643^{* *}$ & $2.399 * *$ & 0.045 & -124.295 & -0.025 & -9.168 \\
\hline & $(0.310)$ & $(1.115)$ & $(0.246)$ & $(189.470)$ & $(0.302)$ & $(5677.132)$ \\
\hline \multirow{2}{*}{ Distance to market } & -0.003 & -0.036 & -0.004 & 2.209 & 0.003 & -0.051 \\
\hline & $(0.004)$ & $(0.026)$ & $(0.003)$ & $(3.109)$ & $(0.003)$ & $(56.680)$ \\
\hline Fertilizer & 1.433 * & -14.699 & $1.262 * * *$ & -537.280 & $0.997^{* *}$ & 25.124 \\
\hline application & $(0.753)$ & $(4198.42)$ & $(0.357)$ & $(782.867)$ & $(0.422)$ & (5561.985) \\
\hline \multirow{2}{*}{ Residue use } & -0.038 & 18.066 & 0.336 & -171.193 & -0.155 & 2.814 \\
\hline & $(0.403)$ & $(3071.12)$ & $(0.340)$ & $(257.801)$ & $(0.377)$ & $(6921.347)$ \\
\hline
\end{tabular}


Table 10. Cont.

\begin{tabular}{|c|c|c|c|c|c|c|}
\hline & \multicolumn{2}{|c|}{ Maize Varieties } & \multicolumn{2}{|c|}{ Sorghum Varieties } & \multicolumn{2}{|c|}{ Groundnut Varieties } \\
\hline & Improved & $\begin{array}{l}\text { Improved } \\
\text { and Local }\end{array}$ & Improved & $\begin{array}{l}\text { Improved } \\
\text { and Local }\end{array}$ & Improved & $\begin{array}{l}\text { Improved } \\
\text { and Local }\end{array}$ \\
\hline Off-farm income & $\begin{array}{l}-0.106 \\
(0.333)\end{array}$ & $\begin{array}{l}-1.037 \\
(1.079)\end{array}$ & $\begin{array}{c}-0.547^{* *} \\
(0.261)\end{array}$ & $\begin{array}{l}-183.823 \\
(258.314)\end{array}$ & $\begin{array}{l}-0.516 \\
(0.325)\end{array}$ & $\begin{array}{c}-0.069 \\
(5092.449)\end{array}$ \\
\hline Grain yield & $\begin{array}{c}0.966^{* * *} \\
(0.611)\end{array}$ & $\begin{array}{c}17.516 \\
(4909.65)\end{array}$ & $\begin{array}{l}0.255^{* *} \\
(0.319)\end{array}$ & $\begin{array}{l}-22.363 \\
(85.800)\end{array}$ & $\begin{array}{l}0.296 \text { * } \\
(0.419)\end{array}$ & $\begin{array}{c}17.306 \\
(8777.624)\end{array}$ \\
\hline Drought tolerance & $\begin{array}{l}0.345^{* *} \\
(0.453)\end{array}$ & $\begin{array}{c}0.707 \\
(1.638)\end{array}$ & $\begin{array}{l}0.350 * \\
(0.293)\end{array}$ & $\begin{array}{c}-944.199 \\
(1267.680)\end{array}$ & $\begin{array}{l}1.148^{* * *} \\
(0.361)\end{array}$ & $\begin{array}{c}-4.167 \\
(6503.621)\end{array}$ \\
\hline Disease resistance & $\begin{array}{l}-0.156 \\
(0.359)\end{array}$ & $\begin{array}{l}-1.805 \\
(1.302)\end{array}$ & $\begin{array}{c}0.365 \\
(0.288)\end{array}$ & $\begin{array}{c}127.620 \\
(193.662)\end{array}$ & $\begin{array}{c}1.256^{* * *} \\
(0.373)\end{array}$ & $\begin{array}{c}-8.081 \\
(4967.972)\end{array}$ \\
\hline Stover yield & $\begin{array}{c}0.433^{* * *} \\
(0.494)\end{array}$ & $\begin{array}{c}-16.187 \\
(1657.89)\end{array}$ & $\begin{array}{l}0.377 * \\
(0.377)\end{array}$ & $\begin{array}{c}397.384 \\
(537.763)\end{array}$ & $\begin{array}{l}0.117^{* *} \\
(0.500)\end{array}$ & $\begin{array}{c}1.392 \\
(9387.032)\end{array}$ \\
\hline Digestibility & $\begin{array}{c}0.338 \\
(0.406)\end{array}$ & $\begin{array}{l}-1.546 \\
(1.772)\end{array}$ & $\begin{array}{c}0.394 \\
(0.339)\end{array}$ & $\begin{array}{c}-56.736 \\
(137.583)\end{array}$ & $\begin{array}{l}-0.395 \\
(0.412)\end{array}$ & $\begin{array}{c}2.158 \\
(14,126.041)\end{array}$ \\
\hline Biomass & $\begin{array}{l}0.250 * * \\
(0.366)\end{array}$ & $\begin{array}{l}2.803 * \\
(1.493)\end{array}$ & $\begin{array}{l}0.112 * * \\
(0.313)\end{array}$ & $\begin{array}{c}131.559 \\
(196.841)\end{array}$ & $\begin{array}{l}0.172 \text { * } \\
(0.325)\end{array}$ & $\begin{array}{c}0.741 \\
(4988.637)\end{array}$ \\
\hline Low lignin & $\begin{array}{l}-0.197 \\
(0.433)\end{array}$ & $\begin{array}{l}-0.085 \\
(1.835)\end{array}$ & $\begin{array}{c}-0.698^{* *} \\
(0.355)\end{array}$ & $\begin{array}{c}83.851 \\
(147.372)\end{array}$ & $\begin{array}{c}0.106 \\
(0.302)\end{array}$ & $\begin{array}{c}-7.976 \\
(4177.169)\end{array}$ \\
\hline Stay green & $\begin{array}{l}-0.571 \\
(0.412)\end{array}$ & $\begin{array}{c}-15.577 \\
(1675.27)\end{array}$ & $\begin{array}{c}0.093 \\
(0.336)\end{array}$ & $\begin{array}{c}48.381 \\
(193.477)\end{array}$ & $\begin{array}{c}0.198 \\
(0.398)\end{array}$ & $\begin{array}{c}0.951 \\
(9948.284)\end{array}$ \\
\hline Dry matter & $\begin{array}{c}0.130 \\
(0.412)\end{array}$ & $\begin{array}{c}-14.165 \\
(1795.09)\end{array}$ & $\begin{array}{l}-0.312 \\
(0.400)\end{array}$ & $\begin{array}{c}141.261 \\
(221.171)\end{array}$ & $\begin{array}{c}0.220 \\
(0.461)\end{array}$ & $\begin{array}{c}-11.898 \\
(11,022.278)\end{array}$ \\
\hline Constant & $\begin{array}{c}1.205 \\
(1.179)\end{array}$ & $\begin{array}{c}-32.633 \\
(5791.07)\end{array}$ & $\begin{array}{c}-2.378^{* * *} \\
(0.883)\end{array}$ & $\begin{array}{c}1080.757 \\
(1460.700)\end{array}$ & $\begin{array}{l}-0.194 \\
(1.058)\end{array}$ & $\begin{array}{c}-44.476 \\
(19,649.000)\end{array}$ \\
\hline Observations & 531 & & 463 & & 350 & \\
\hline Prob > chi ${ }^{2}$ & 0.002 & & 0.000 & & 0.061 & \\
\hline Pseudo $\mathrm{R}^{2}$ & 0.161 & & 0.192 & & 0.140 & \\
\hline
\end{tabular}

Standard errors in parentheses. ${ }^{*} p<0.05 ;{ }^{* *} p<0.01 ;{ }^{* * *} p<0.001$.

\section{Discussions}

Our results confirm that mixed crop-livestock systems are the dominant farming systems in the drylands of Zimbabwe. Lack of adequate fodder was the most limiting constraint for livestock production in the study districts, as has already been reported elsewhere [10,26]. Maize, sorghum, and groundnut constitute the key crops in these systems, combinedly accounting for more than $75 \%$ of households' farming lands. There are, however, substantial differences in the intensification of the cropping systems of the three crops. Many farmers grow improved varieties of maize, but local varieties of sorghum and groundnut. These crops are grown primarily for consumption; only small proportions of maize and groundnut grains are marketed. Crop residuals are significant feed sources in the study districts, after natural rangeland grazing.

Farmers value a wide range of traits of dual-purpose crops. Overall, yield and field characteristics, such as yield, drought tolerance, and disease resistance, were highly rated in importance. Particularly, yield was the most important attribute across all three crops. Farmers also appreciate several feed quality and quantity attributes of dual-purpose crops. Stover yield and digestibility came first in this group of attributes and were important for all crops. Farmers also found biomass yield, low lignin, stay green, and dry matter to be important feed attributes. Generally, the results reveal a potentially high demand for dual-purpose varieties in mixed crop-livestock systems of the study areas.

As varieties bred explicitly for dual-purpose were not yet readily available for adoption in the study districts of Zimbabwe, elicitation of the different traits and their importance was done independently of consideration of specific varieties. Therefore, the farmers' preferences should be interpreted as a potential demand for dual-purpose varieties rather 
than the evaluation of demand for specific varieties [11]. Preferences for many feed traits were strongly correlated with the likelihood of growing dual-purpose crops. Specifically, stover yield, biomass, and stay green traits were positively and significantly associated with farmers' likelihood of growing dual-purpose crops. Maize and groundnut farmers who reported drought tolerance as an important attribute were also more likely to grow dual-purpose crops. However, grain yield is significantly and negatively correlated with the likelihood of producing dual-purpose crops by maize farmers, perhaps suggesting potential trade-offs between grain and field attributes and feed attributes in dual-purpose varieties. As expected, livestock ownership and feeding livestock on residues increased the probability of growing dual-purpose varieties. The likelihood of producing dual-purpose crops increases with household size, fertilizer application, and credit access, but decreases with distance to market and off-farm income opportunities.

Stated trait preferences were significantly correlated with adoption of improved varieties of maize, sorghum, and groundnut, and production of dual-purpose crops. Mainly, grain and field traits such as yield and drought tolerance are strongly correlated with the adoption of improved varieties. The results also indicate that good biomass and stover quality could improve the likelihood of adoption of improved varieties. The likelihood of growing improved varieties increases with farmers' access to extension services and fertilizer application, probably indicating the importance of rural services and complementarity of other technologies to improve farmers' adoption of improved varieties. The probability of growing maize improved varieties increases with age, credit access, and education levels. This might be an indication that these factors increase opportunities for maize farmers. The likelihood of adopting maize and sorghum improved varieties also increases with household size. However, male-headed households and households engaged in farming as their main occupation were less likely to adopt improved varieties.

These findings matter because they could explain the low adoption rates of high-yield varieties, particularly of sorghum and groundnuts, in Zimbabwe over the last several decades. This is critical because varieties promoted only based on their improved agronomic traits often face adoption challenges [38,39]. Despite the large number of varieties released, the velocity of varietal change is found to be low in the three target crops. Some old varieties are still remarkably widely grown in the face of many new varieties being released. The average age of the widely grown varieties of the three crops is effectively greater than 10 (Table 1). This would limit the realization of high rates of genetic gains generated by breeding programs in staple crops. Rapid varietal replacement is needed to avoid yield losses due to the evolution of pests and diseases in the face of climate change and frequent shocks in drylands.

More analysis is needed to understand the causes of the robustness of old varieties, while newly released varieties remain on the shelf. Several hypotheses may equally be at work here. First, improved varieties might not have met the preferences of farmers and other value chain stakeholders. Second, there is a lack of robust data to support the commercialization decisions of seed enterprises who would ensure sustained availability/access to planting material. Third, there may be limited awareness of the existence of improved varieties as private sector stakeholders have not invested in promotion and marketing of such varieties well. Fourth, the seed systems may be ill-equipped to respond to the demand for seed of improved varieties. There is tentative evidence that formal and informal seed markets can partially explain the lack of diffusion of dual-purpose crops in rural Zimbabwe. While the maize seed market in Zimbabwe is well developed, farmers still have poor access to good quality seed of improved sorghum and groundnuts preferred by farmers and grain markets [40]. Formal seed markets are also reluctant to handle seeds of these crops due to thin profit margins.

Alternatively, recent research might have not always succeeded in producing varieties bundling farmers' preferences for different traits. Perhaps efforts promoting improved varieties are likely to be successful if they package information on different attributes of new varieties rather than focusing solely on usual agronomic traits. Our findings resonate 
with similar studies elsewhere, for instance, the authors of [11], who report that stover quantity and quality are important criteria in farmers' assessment of maize cultivars in crop-livestock farming systems in Ethiopia and Tanzania. Other studies point out that farmers' interests in adopting and using improved varieties of grain crops reflect their trait valuations and preferences [34,41,42].

Finally, more research is needed in this area before making more general statements of findings, like ours. While farmers express interest in many feed quantity and quality attributes, they might not accept dual-purpose varieties that compromise on other attributes, particularly yield. Though some evidence elsewhere has suggested that biomass and yield goals of improved varieties may not necessarily be in conflict [43], there is a need for more research on potential trade-offs between feed attributes and other attributes, including grain and field attributes, consumer (e.g., taste) and market (e.g., seed and grain price) attributes, in dual-purpose varieties. Specifically, further research is needed to explore acceptable thresholds in these trade-offs, particularly with traits that farmers appreciate most so that farmers remain interested in adopting the improved varieties. Finally, new varieties must fit smallholder farming systems, including the biophysical conditions, such as climate and soil [44]. Thus, for new varieties to succeed, crop improvement programs must understand the farmers' needs adapted to their farming systems [39].

\section{Conclusions}

The results of this study indicate that mixed crop-livestock systems are the dominant farming systems in the study districts. Maize, sorghum, and groundnut are the major crops, accounting for more than $75 \%$ of households' cropping lands. Farmers generally grow improved maize varieties, but largely local varieties of sorghum and groundnut. Lack of adequate feed was the most limiting constraint for livestock production in the study districts. Yield, drought tolerance, and disease resistance were highly rated in importance in farmers' choice of varieties. Farmers also considered feed quality and quantity attributes important in their choice of dual-purpose varieties. Stover yield and digestibility, along with biomass yield, stay green, and dry matter, were found to be important feed attributes for farmers. This suggests that there is a potentially high demand for dual-purpose crops. Farmers' stated preferences for (some) yield and feed attributes were significantly correlated with the likelihood of production of dual-purpose crops and growing improved varieties, but the degree of correlations varied across crops.

Our study results have important implications for breeding, targeting, and development of dual-purpose varieties of the target crops in Zimbabwe. We show that farmers are interested in varieties with high grain yield, disease-resistance, drought-tolerance, and enhanced feed quality and quantity. To shorten the average age of dominant varieties for all crops and realize genetic gains, breeding programs must match farmers' preferences and trait needs. Specifically, trade-offs between preferred traits must be addressed. Finally, our results suggest that dual-purpose varieties should not compromise grain and field attributes that farmers usually consider important. This is critical to ensure the adoption of improved dual-purpose cultivars at scale for greater impact in developing countries. Overall, our results are insightful for crop improvement teams to define and refine customer-oriented and market-driven product profiles for breeding programs.

Author Contributions: Conceptualization, M.B.M. and M.H.; methodology, M.B.M., A.N.T. and M.H.; formal analysis and investigation, M.B.M., A.N.T. and M.H.; software and data curation, M.B.M. and A.N.T.; resources, C.O.O. and M.H.; writing-original draft preparation, M.B.M. and A.N.T.; writing-review and editing. All authors have read and agreed to the published version of the manuscript.

Funding: The APC was funded by the Open Access Support of the Bill \& Melinda Gates Foundation.

Institutional Review Board Statement: The study was conducted according to the guidelines of the Declaration of Helsinki.

Informed Consent Statement: Informed consent was obtained from all subjects involved in the study. 
Data Availability Statement: The data presented in this study are available upon request from the authors.

Acknowledgments: The authors are grateful to Sabine Homann-Kee Tui, Hapson Mushoriwa, Kumar Charyulu, Anthony Whitbread, and Claid Mujaju for their support in the development of the manuscript. We thank Thabani Dube for his assistance in the fieldwork.

Conflicts of Interest: The authors declare no conflict of interest.

\section{References}

1. Lenné, J.M.; Thomas, D. Integrating crop-Livestock research and development in sub-Saharan Africa: Option, imperative or impossible? Outlook Agric. 2006, 35, 167-175. [CrossRef]

2. FAO. The Economic Lives of Smallholder Farmers: An Analysis Based on Household Data from Nine Countries; FAO: Rome, Italy, 2015.

3. McIntire, J.; Gryseels, G. Crop-Livestock Interactions in Sub-Saharan Africa and their Implications for Farming Systems Research. Exp. Agric. 1987, 23, 235-243. [CrossRef]

4. FAO. Mixed Crop-Livestock Systems; FAO: Rome, Italy, 2001.

5. Salmon, G.; Teufel, N.; Baltenweck, I.; van Wijk, M.; Claessens, L.; Marshall, K. Trade-offs in livestock development at farm level: Different actors with different objectives. Glob. Food Secur. 2018, 17, 103-112. [CrossRef]

6. Tarawali, S.; Herrero, M.; Descheemaeker, K.; Grings, E.; Blümmel, M. Pathways for sustainable development of mixed crop livestock systems: Taking a livestock and pro-poor approach. Livest. Sci. 2011, 139, 11-21. [CrossRef]

7. Valbuena, D.; Erenstein, O.; Homann-Kee Tui, S.; Abdoulaye, T.; Claessens, L.; Duncan, A.J.; Gerard, B.; Rufino, M.C.; Teufel, N.; van Rooyen, A.; et al. Conservation agriculture in mixed crop-livestock systems: Scoping crop residue trade-offs in Sub-Saharan Africa and South Asia. Field Crop. Res. 2012, 132, 175-184. [CrossRef]

8. Garrett, R.D.; Niles, M.; Gil, J.D.B.; Dy, P.; Reis, J.; Valentim, J. Policies for Reintegrating Crop and Livestock Systems: A Comparative Analysis. Sustainability 2017, 9, 473. [CrossRef]

9. Katema, T.; Mwakiwa, E.; Hanyani-Mlambo, B.T.; Gomera, M.R.; Chamboko, T. An analysis of the profitability of groundnut production by smallholder farmers in Chegutu district, Zimbabwe. J. Econ. Sustain. Dev. 2017, 8, 167-175.

10. Mapiye, C.; Mwale, M.; Chikumba, N.; Poshiwa, X.; Mupangwa, J.F.; Mugabe, P.H. A review of improved forage grasses in Zimbabwe. Trop. Subtrop. Agroecosystems 2006, 6, 125-131.

11. De Groote, H.; Dema, G.; Sonda, G.B.; Gitonga, Z.M. Maize for food and feed in East Africa-The farmers' perspective. Field Crop. Res. 2013, 153, 22-36. [CrossRef]

12. Herrero, M.; Thornton, P.K.; Notenbaert, A.; Msangi, S.; Wood, S.; Kruska, R.; Dixon, J.; Bossio, D.; Steeg, J.V.D.; Freeman, H.A.; et al. Drivers of Change in Crop-Livestock Systems and Their Potential Impacts on Agroecosystems Services and Human Wellbeing to 2030: A Study Commissioned by the CGIAR Systemwide Livestock Programme; ILRI: Nairobi, Kenya, 2007.

13. Romney, D.L.; Thorne, P.; Lukuyu, B.; Thornton, P.K. Maize as food and feed in in-tensive smallholder systems: Management options for improved integration in mixed farming systems of east and southern Africa. Field Crop. Res. 2003, 84, 159-168. [CrossRef]

14. Rufino, M.C.; Dury, J.; Tittonell, P.; van Wijk, M.T.; Herrero, M.; Zingore, S.; Mapfumo, P.; Giller, K.E. Competing use of organic resources, village-level interactions between farm types and climate variability in a communal area of NE Zimbabwe. Agric. Syst. 2011, 104, 175-190. [CrossRef]

15. Erenstein, O.; Blümmel, M.; Grings, E. Potential for dual-purpose maize varieties to meet changing maize demands: Overview. Field Crop. Res. 2013, 153,1-4. [CrossRef]

16. Snapp, S.; Rahmanian, M.; Batello, C. Pulse Crops for Sustainable Farms in Sub-Saharan Africa; United Nations Publications: Rome, Italy, 2018.

17. Hall, A.; Blümmel, M.; Thorpe, W.; Bidinger, F.R.; Hash, C.T. Sorghum and Pearl Millet as food-feed-crops in India. Anim. Nutr. Feed Technol. 2004, 4, 1-15.

18. Blümmel, M.; Anandan, S.; Wright, I.A. Improvement of feed resources and livestock feeding in mixed cropping systems. In Animal Nutrition Advances and Development; Mehra, U.R., Singh, P., Verma, A.K., Eds.; Satish Serial Publishing House: New Delhi, India, 2012; pp. 459-475.

19. Hassan, S.A.; Mohammed, M.I.; Yagoub, S.O. Breeding for dual purpose attributes in sorghum: Effect of harvest option and genotype on fodder and grain yields. J. Plant Breed. Crop Sci. 2015, 7, 101-106.

20. Bell, L.W.; Moore, A.D.; Kirkegaard, J.A. Evolution in crop-livestock integration systems that improve farm productivity and environmental performance in Australia. Eur. J. Agron. 2014, 57, 10-20. [CrossRef]

21. Mkuhlani, S.; Mupangwa, W.; MacLeod, N.; Gwiriri, L.; Nyagumbo, I.; Manyawu, G.; Chigede, N. Crop-livestock integration in smallholder farming systems of Goromonzi and Murehwa, Zimbabwe. Renew. Agric. Food Syst. 2018, 35, 249-260. [CrossRef]

22. Lenne, J.M.; Fernandez-Rivera, S.; Blümmel, M. Approaches to improve the utilization of food-feed crops: Synthesis. Field Crop. Res. 2003, 84, 213-222. [CrossRef]

23. Sharma, K.; Pattanaik, A.K.; Anandan, S.; Blümmel, M. Food-Feed crops research: A synthesis. Anim. Nutr. Feed Technol. 2010, 10, 1-10. 
24. Edilegnaw, W.; Asmare, Y. Farmers' variety attribute preferences: Implications for breeding priority setting and agricultural extension policy in Ethiopia. Afr. Dev. Rev. 2007, 19, 379-396.

25. Edmeades, S. A hedonic approach to estimating the supply of variety attributes of a sub-sistence crop. Agric. Econ. 2007, 37, 19-28. [CrossRef]

26. Mupangwa, W.; Thierfelder, C. Intensification of conservation agriculture systems for increased livestock feed and maize production in Zimbabwe. Int. J. Agric. Sustain. 2013, 12, 425-439. [CrossRef]

27. Tui, S.H.-K.; Blümmel, M.; Valbuena, D.; Chirima, A.; Masikati, P.; van Rooyen, A.F.; Kassie, G.T. Assessing the potential of dual-purpose maize in southern Africa: A multi-level approach. Field Crop. Res. 2013, 153, 37-51. [CrossRef]

28. Henderson, B.; Godde, C.; Medina-Hidalgo, D.; van Wijk, M.; Silvestri, S.; Douxchamps, S.; Stephenson, E.; Power, B.; Rigolot, C.; Cacho, O.; et al. Closing system-wide yield gaps to increase food production and mitigate GHGs among mixed crop-livestock smallholders in Sub-Saharan Africa. Agric. Syst. 2016, 143, 106-113. [CrossRef] [PubMed]

29. Ryschawy, J.; Choisis, N.; Choisis, J.; Joannon, A.; Gibon, A. Mixed crop-livestock systems: An economic and environmentalfriendly way of farming? Animals 2012, 6, 1722-1730. [CrossRef]

30. Chikobvu, S.; Kassie, G.T.; Lunduka, R.W. Socio-Economics Program Working Paper. In Adoption of Drought Tolerant Maize Varieties in Zimbabwe. Country Report-DT Maize Adoption Monitoring Survey-Zimbabwe; CIMMYT: Mexico City, Mexico, 2014.

31. Musara, J.P.; Musemwa, L.; Mutenje, M.; Mushunje, A.; Pfukwa, C. Determinants of sorghum adoption and land allocation intensity in the smallholder sector of semi-arid Zimbabwe. Span. J. Agric. Res. 2019, 17, e0105. [CrossRef]

32. Mohanraj, K.; Gopalan, A.; Durai, A.A.; Ravinder, K. Genetic variability for grain cum fodder yield and contributing traits in F2 generations of dual-purpose sorghum. Plant Arch. 2011, 11, 151-156.

33. Tekle, D.; Gebru, G. The effect of haulms of groundnut and cowpea supplementations on growth performance of Abergelle goats. Livest. Res. Rural Dev. 2018, 30, 3.

34. Kassie, G.T.; Abdulai, A.; Greene, W.H.; Shiferaw, B.; Abate, T.; Tarekegne, A.; Sutcliffe, C. Modeling Preference and Willingness to Pay for Drought Tolerance (DT) in Maize in Rural Zimbabwe. World Dev. 2017, 94, 465-477. [CrossRef] [PubMed]

35. Kristjanson, P.M.; Zerbini, E. Genetic enhancement of sorghum and millet residues fed to ruminants: An ex ante assessment of returns to research. In Impact Assessment Series 3; ILRI: Nairobi, Kenya, 1999.

36. Boone, H.N.; Boone, D.A. Analyzing Likert Data. Journal of Extension 50, Article Number 2TOT2. 2012. Available online: http:/ / www.joe.org/joe/2012april/tt2.php (accessed on 12 November 2020).

37. Greene, W.H. Econometric Analysis; Pearson Education Inc.: Upper Saddle River, NJ, USA, 2003.

38. Muzhingi, T.; Langyintuo, A.S.; Malaba, L.C.; Banziger, M. Consumer acceptability of yellow maize products in Zimbabwe. Food Policy 2008, 33, 352-361. [CrossRef]

39. Ekpa, O.; Palacios-Rojas, N.; Kruseman, G.; Fogliano, V.; Linnemann, A.R. Sub-Saharan African maize-based foods: Technological perspectives to increase the food and nutrition security impacts of maize breeding programmes. Glob. Food Secur. 2018, 17, 48-56. [CrossRef]

40. Phiri, K.; Dube, T.; Moyo, P.; Ncube, C.; Ndlovu, S.; Buchenrieder, G. Small grains "resistance"? Making sense of Zimbabwean smallholder farmers' cropping choices and patterns within a climate change context. Cogent Soc. Sci. 2019, 5, 1622485. [CrossRef]

41. Khanal, U.; Adhikari, A.; Wilson, C. Evaluating smallholder farmers' demand for rice variety attributes in Nepal. J. Crop. Improv. 2017, 92, 1-15. [CrossRef]

42. Daudi, H.; Shimelis, H.; Laing, M.; Okori, P.; Mponda, O. Groundnut production constraints, farming systems, and farmerpreferred traits in Tanzania. J. Crop. Improv. 2018, 32, 812-828. [CrossRef]

43. Zaidi, P.; Vinayan, M.; Blümmel, M. Genetic variability of tropical maize stover quality and the potential for genetic improvement of food-feed value in India. Field Crop. Res. 2013, 153, 94-101. [CrossRef]

44. Sunding, D.; Zilberman, D. The agricultural innovation process: Research and technology adoption in a changing agricultural sector. In Handbook of Agricultural Economics; Bruce, L.G., Gordon, C.R., Eds.; Elsevier: Amsterdam, The Netherlands, 2001; pp. 207-261. [CrossRef] 